\title{
Impact of Stock Market Liquidity on Investment of Listed Enterprises: Evidence from Vietnam
}

\author{
TRAN NGOC THO \\ University of Economics HCMC - thotcdn@ueh.edu.vn \\ DANG NHU Y \\ Far East National Bank - HCMC branch - dangnhuytc9@gmail.com
}

\section{ARTICLE INFO ABSTRACT}

Article history:

Received:

May 11, 2015

Received in revised form:

Oct. 07,2015

Accepted:

Sep. 23, 2016

Keywords:

Firm investment, liquidity, D-GMM.
This paper studies the effects of market liquidity and other factors on investment of non-financial companies listed on Vietnam's stock exchange for the 2008-2013 period by adopting different measures of investment and liquidity, and considering the impact of interaction between liquidity and others, including issuing, financial constraints, and growth opportunities, on firm investment. The estimated results of DGMM with fixed effects and interacting variables prove that stock market liquidity negatively relates to the investment. We do not find any compelling evidence of the liquidity-investment nexus among firms with tighter financial constraints and better investment opportunities. However, we do find the relations between firm investment and financial leverage and also firm investment and cash flows. 


\section{Introduction}

Liquidity of Vietnam's stock market, in recent years, has soared with the participation of domestic and foreign investors, as well as other specialized organizations. A rise in market liquidity is expected to entail large capital sources along with low costs of capital use, promoting investment in the economy in general and corporate investment in particular. When the stock market liquidity rises, its impact on investment among enterprise becomes a matter of concern.

Two different perspectives govern the development of research into liquidity effects on firm investment. The first maintains that stock market liquidity positively and significantly affect investment of enterprises through several interacting variables such as stock issuance, financial constraints, and growth opportunities. A few typical studies include Muñoz (2012), Polk and Sapienza (2009), Gilchrist et al. (2005), and Butler et al. (2005). From another perspective, Fange et al. (2014), Stein (1988, 1989, 1996), and McGahan et al. (1997) argued that market liquidity becomes a hindrance to firm investment via managerial myopia and market characteristics with the concentration of transient institutional investors.

The above studies also proposed various techniques for measuring investment and liquidity, most of which involve using growth in fixed asset and capital expenditure as a measure of investment. Nevertheless, Muñoz (2012) suggested rational alternatives for the case of Latin American market, including growth in total assets that wholly represents growth in investment and growth in inventories reflecting on the firm's shortterm investment, especially for those that require a range of inventories in trading business. In addition, Muñoz (2012) and Lesmond (2005) utilized trading volume as a liquidity measure, employing daily data on the number of shares traded and the total number of shares floating of the firm (with elimination of abnormal trading days when the trading volume is greater than the total number of shares). Another liquidity measure is industry-adjusted trading volume as advocated by Muñoz (2012) and Sadka and Scherbina (2007).

In Vietnam a few individual investigations have been performed into the relations of either investment decision or stock market liquidity and others. Since no specific study focuses on analyzing the investment-liquidity nexus in the country, this study addresses this issue at the firm level using different measures of investment and liquidity besides the impact of stock market liquidity on firm investment through various transmission 
channels. These relationships are pinpointed in the case of availability of additional stock issuance with different financial constraints and growth opportunities.

We employ regression technique for panel data and control for fixed effects and other interacting variables based on the D-GMM approach. Instrument variables are also applied to the panel data of 366 non-financial enterprises listed on the Vietnam's stock market over the years of 2008-2013.

\section{Theoretical bases and methodology}

2.1. Impact of liquidity and other factors on firms' investment policy and related transmission channels

2.1.1. Effects of liquidity and transmission channels on firm investment

Intermediate transmission channels and the impact of the liquidity on investment at the firm level have not made any specific prediction about the direction as well as the direct effect of liquidity on firm investment as typically reported by Edmans and Manso (2011). The studies considering the transmission channel centered on two key issues: agency costs and information asymmetry in the firm. It was argued that higher market liquidity enables the share price to reflect more on the information and enhances supervising activities of investors, thereby reducing agency costs and financial constraints in addition to improving business performance and magnifying real investments.

The studies relating to positive transmission channels of the impact of liquidity on firm investment addressed three key issues, comprising mispricing and dispersion of stock analysts' predictions (Gilchrist et al., 2005), overconfidence and heterogeneous expectations (Banerjee \& Kremer, 2010), and costs of issuance and additional stock issuance (Polk \& Sapienza, 2009; Butler et al., 2005). These works endeavored to pinpoint the issue based on mispricing including differences in analysts' forecasts of business results that lead to differences in investors' expectations, combined with shortselling constraints conducive to stock market bubbles and favorable conditions for the issuance of additional stock issuance at low costs. With the availability of low-cost capital sources, firms would likely invest more.

Others concerning negative transmission channels generated discussions on information asymmetry, market pressure, and market characteristics with high levels of 
swing trading and management's myopic behavior. Stein (1988, 1989, 1996), Porter (1992, 1997), and Fang (2014) agreed that intense swing trading in the market creates pressure that leads to managerial myopia, particularly an exchange of great investment opportunities for short-term growth, thus reducing investment among businesses, especially those with low profits.

2.1.2. Effects of other factors on firm investment policy

- Impact of investment opportunities on firm investment policy

The grounded theories on investment policy of enterprises argued that it depends only on profitability obtained from investment opportunities and is measured by Tobin's Q. The ratio is also described as an endogenous variable in the model, which is overcome by regression or variable substitution approaches. Additionally, according to Muñoz (2012), both Tobin's Q and the book-to-market ratio are fine proxies for firm's investment opportunities. Specifically, Tobin's Q is positively and significantly correlated with firm investment, implying that growth opportunities motivate investment activities and that the impact of liquidity on investment varies dramastically among firms with different opportunities to grow.

- Impact of financial constraints on firm investment policy

It is commonly suggested that firms that are financially constrained are likely to be more sensitive to liquidity, and small-sized enterprises receive few external financing sources. Accordingly, liquidity would narrow such a gap for small firms, thus bringing in more investments from them. Muñoz (2012) found evidence of different levels of liquidity impact on investments of firms with varied financial constraints, which are measured by differentiating large from small enterprises on the basis of average total assets.

\subsection{Methodology}

\subsubsection{Research model}

The paper inspects the nexus between stock market liquidity and firm investment policy, using the yearly data of non-financial firms listed on Vietnam's stock exchange between 2008 and 2013. The following equation is computed to estimate effects of liquidity and other control variables on real investment:

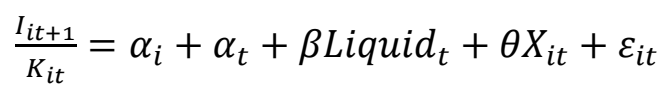


where $i$ and $t$ denote firm and year respectively.

Investment $(I / K)$ and liquidity of firm stocks (Liquid) are calculated using Muñoz's (2012) measures, which, however, are adjusted to suit the distinctive data of Vietnam's enterprises. Leverage, Tobin's Q, and Cash Flow are control variables in the model. We use such dummy variables as High B/M, Large, and Issue in combination with liquidity to constitute interaction variables. Particularly, we consider using additional interacting variables between defined dummy variables in case firms issue stocks (Issue) or if they are 'growth' firms or 'value' (high $\mathrm{B} / \mathrm{M}$ ) firms or between firm size (Large) and indicators of liquidity.

Furthermore, we employ fixed effects at the firm level $\left(\alpha_{\mathrm{i}}\right)$ to identify firm's distinctive characteristics constant over time. Specifically, control variables include: (i) Leverage, measured by total loans as a ratio to total assets; (ii) Tobin's Q, measured by the ratio of market value of assets to their book value (market value is estimated by total assets plus market capitalization value at the end of year $t$ minus book value of share capital); and (iii) Cash Flow, representing the problem of financial constraints potentially facing a firm, determined by the firm's cash flow standardized by capital value (total assets) at the beginning of year $t$, and measured by net income before adjustment made to infrequent additional amounts plus depreciation of fixed assets, followed by adjustment to total assets.

Firm size (Large) is a dummy variable, equalling the value of 1 for large-sized firms with total assets being larger than the average value of the data sample, and 0 otherwise. Stock issuance (Issue) denotes the firm's issuance of shares in the financial year; it equals 1 for those with new issuance and 0 otherwise. Grow opportunity (High B/M) indicates whether the firm is characterized as being "growth" or "value", taking the value of 1 for the "value" one whose $\mathrm{B} / \mathrm{M}$ value is higher than the average value of the data sample, and 0 for the "growth" one whose B/M value is less than the average value of the data sample.

\section{Measuring investment}

In Equation (1) we consider investment in accordance with four different perspectives relating to firm investment activities, including capital expenditure, growth in assets, growth in fixed assets, and growth in inventories, correspondingly noted as Capex, Total Assets, PPE, and Inventories. We also take into account the whole concept of 
investment, testing the robustness of the regression model via the estimated data in different views and reflecting on firm investment in specific fields.

\section{Measuring liquidity}

Two different approaches to liquidity estimation are employed. The primary one is typified by using trading volume. We adopt daily data on the quantity of shares traded and the total floating shares without consideration of the days on which the total trading volume is larger than total shares floating of the firm. The second technique features the industry-adjusted trading volume, calculated by using the average firm's trading volume adjusted by industry for each year.

Trading volume, in fact, is a measure typical of expected discrepancy and can be used as a proxy for the anticipated dissonance after eliminating the impact of the economic cycle. In addition, the trading volume is used to describe investment outlook and information on the price, specific to investment through mispricing of assets, overconfidence, and asymmetry in expectations, as well as issuance expenses and issuance of additional shares.

2.2.2. Research data

To estimate Equation (1) we gather data for non-financial firms listed on Vietnam's stock market for the period of 2007-2013. One criterion for data collection is that the duration of observation for each enterprise should be five years at least, and importantly, the data for 2009-2013 should be sufficient to satisfy the condition for time series in the panel data structure. Furthermore, we apply a few criteria for stringent data filtering from earlier findings to avoid the problem of outliers in the data sample. The ultimate sample includes 366 non-financial firms (162 listed on HOSE and 204 on HNX) during 20082013.

\subsubsection{D-GMM estimation}

The purpose of this study is to tackle three major problems in calculating Equation (1) in association with the fact that the Tobin's Q can be an endogenous variable due to the impact of current shocks on prices or that it cannot be a sound proxy for firm's growth opportunity or that error arises from estimating Tobin's Q. To such extent we decide between two of the following approaches to the stated endogeniety: 
The first approach takes differences from the model and uses lags of endogenous variables as instrument variables, which can be regressed by employing either IV-OLS or GMM techniques.

The second approach maintains the origin of the model and uses lags of first differences of instrument variables with regression using the IV-OLS estimate.

In light of the results from Hasan test, F test, and weak-instrument robust tests, we opt for the first approach, i.e. we take differences from the model and use lags of endogenous variables as instrument variables with D-GMM estimation (the Differenced GMM proves efficient in overcoming the problem of fixed effects constant over time that can be correlated with exploratory variables and suitable for "large N, small T" panel data). The instrument variable may fall into two categories, including the available variables in the model (in differences - also applied to control variables on the right side of Equation (1)) except for Tobin's Q and lags (lag-1 and lag-2) of difference of Tobin's $\mathrm{Q}$, which are not involved in the primary model.

We also utilize three interacting variables: between trading volume/industry-adjusted trading volume and share issuance, between trading volume/industry-adjusted trading volume and firm size, and between trading volume/industry-adjusted trading volume and the one representing growth/value firm as mentioned earlier. We then check robustness of the estimated results from Equation (1) using Hansen test for validity and credentiality of the set of instrument variables as well as Stock-Wright LM S statistic for its robustness.

\subsubsection{Orienting estimations}

As mentioned in Equation (1), the main hypothesis is that $\beta$ is positive and significant, reflecting on higher liquidity and thereby on more intensive investment. This fact exposes the effects of the mispricing channel and issuance costs.

To test the difference between transmission channels, we focus on the scenario where firms have decided to issue shares and examine whether the relation between investment and liquidity becomes more significant. To test such hypothesis interactions are to be added to the original regression equation between a defined dummy variable if the firm issues more shares and the indicators of liquidity. When this parameter is positive and significant, it implies that a nexus exists between the mispricing channel in the circumstance of further issued shares and cost of the issuance channel. 
The issue of financial constraints with their effect on the correlation between firm investment and liquidity is also tested by adding to the original regression equation a dummy variable to proxy for firm size (large or small) and its interaction with the indicators of liquidity. The negative and significant parameter indicates that the impact of market liquidity is not often congruent with firm's financial constraints.

Finally, concerning liquidity and its role in promoting investment, the effect is more evident in those with abundant investment opportunities. To check this we add to the model a dummy variable that represents the "growth" or "value" firm, and also examine its interaction with the indicators of liquidity. A negative and significant coefficient can demonstrate the inconsistency of liquidity effects among firms with dissimilar investment opportunities.

\section{Empirical results}

We collect yearly data of 366 firms listed on Vietnam's stock exchange over the 2008-2013 period, bearing in mind that the data for five consecutive terms should be available for each firm. All the variables are adjusted using winsorization technique at $1 \%$ level to minimize the influence of outliers at each tail potentially causing spurious results.

Dependent variables are growth in total assets (Total Asset), growth in fixed assets (PPE), growth in inventories (Inventory), and capital expenditure (Capex), all of which are defined in $\Delta I_{t+1}=\left(I_{t+1}-I_{t}\right) / I_{t}$.

Control variables include: (i) trading volume (Trading Vol.), determined by the adjusted yearly average shares traded and total floating shares; (ii) trading volume and industry (Trading Vol./Ind. - adjusted yearly average shares traded and average industry shares of the same term; (iii) leverage (Leverage - the ratio of total loans to total assets; (iv) Tobin's Q, defined by (market capitalization + total loans)/total assets; and (v) cash flow (Cash Flow), estimated by (EBIT + depreciation)/total assets.

Interacting variables comprise Issue (more share issuance in the year of observation), High B/M ("value" firm if B/M is higher than the market level), and Large (large firm with total assets larger than the average market level). 


\section{Table 1}

Data statistics

\begin{tabular}{lccccc}
\hline Variable & Obs. & Mean & Std. Dev. & Min & Max \\
\hline Investment & & & & & \\
Total Asset & 2,099 & 0.1505 & 0.2645 & -0.3334 & 1.2481 \\
PPE & 2,099 & 0.3299 & 1.2590 & -0.6777 & 8.9130 \\
Inventory & 2,099 & 0.1044 & 0.4444 & -0.7958 & 1.9179 \\
Capex & 2,099 & 0.0256 & 0.1071 & -0.1519 & 0.6052 \\
\hline Liquidity & & & & & \\
Trading Vol. & 2,099 & 0.0045 & 0.0054 & 0.0000 & 0.0271 \\
Trading Vol./Ind. & 2,099 & 1.0078 & 1.6792 & 0.0021 & 9.4981 \\
\hline Control & & & & & \\
Leverage & 2,099 & 0.5200 & 0.2178 & 0.0505 & 0.8871 \\
Tobin's Q & 2,099 & 1.0974 & 0.4385 & 0.4861 & 3.2647 \\
Cash Flow & 2,099 & 0.1771 & 0.1340 & -0.0717 & 0.6741 \\
\hline Interacting & 2,099 & 0.5102 & 0.5000 & 0 & 1 \\
Issue & 2,099 & 0.2187 & 0.4134 & 0 & 1 \\
High B/M & & & & 0 & 1 \\
Large & 2,099 & 0.1729 & 0.3783 & & \\
\hline & 2,099 & & & \\
\hline
\end{tabular}

\section{Table 2}

Estimated results with Trading Vol. and Trading Vol./Ind. as measures of liquidity

\begin{tabular}{lccccccccc}
\hline & Total & PPE & Inventory & Capex & Total & PPE & Inventory & Capex \\
Variable & Asset & $(1)$ & $(2)$ & $(3)$ & $(4)$ & $(1)$ & $(2)$ & $(3)$ & $(4)$ \\
& $(1)$ & & & & & & \\
\hline Tobin's Q & 0.0916 & $2.4873^{* *}$ & $-0.4127^{*}$ & $0.1632^{* *}$ & 0.1206 & $1.6496^{*}$ & $-0.2913^{*}$ & $0.1021^{*}$ \\
& $(0.1277)$ & $(1.229)$ & $(0.2126)$ & $(0.0691)$ & $(0.0967)$ & $(0.888)$ & $(0.1746)$ & $(0.0547)$
\end{tabular}

Trading Vol. 


\begin{tabular}{lcccccccc}
\hline & Total & PPE & Inventory & Capex & Total & PPE & Inventory Capex \\
Variable & Asset & $(2)$ & $(3)$ & $(4)$ & asset & (1) & (2) & (3) \\
\hline
\end{tabular}

$(3.5319)(26.3472)(5.2822) \quad(1.4553)$

\begin{tabular}{|c|c|c|c|c|c|c|c|c|}
\hline \multirow[t]{2}{*}{ Trading Vol./Ind. } & & & & & $-0.0229 *$ & $-0.1272 * *$ & $-0.0086^{*}$ & $-0.0067 * *$ \\
\hline & & & & & $(0.0124)$ & $(0.0877)$ & $(0.0155)$ & $(0.0063)$ \\
\hline \multirow[t]{2}{*}{ Leverage } & $1.6864 * * *$ & $1.3328 * *$ & $2.0591 * * *$ & $0.1677 * * *$ & $1.6518 * * *$ & $1.4453 * *$ & $2.0347 * * *$ & $0.1791 * * *$ \\
\hline & $(0.1369)$ & $(0.6508)$ & $(0.2314)$ & $(0.0552)$ & $(0.1342)$ & $(0.5852)$ & $(0.2272)$ & $(0.0526)$ \\
\hline \multirow[t]{2}{*}{ Cash Flow } & $1.5309 * * *$ & $1.0401 * *$ & $2.189 * * *$ & $0.1844 * * *$ & $1.5101 * * *$ & $=1.1623 *$ & $2.2069 * * *$ & $0.188^{* * *}$ \\
\hline & $(0.1359)$ & $(0.7525)$ & $(0.2317)$ & $(0.0636)$ & $(0.1359)$ & $(0.7222)$ & $(0.2291)$ & $(0.0624)$ \\
\hline Observations & 1001 & 1001 & 1001 & 1001 & 1001 & 1001 & 1001 & 1001 \\
\hline Number of firms & 366 & 366 & 366 & 366 & 366 & 366 & 366 & 366 \\
\hline Hansen test (p_value) & 0.0367 & 0.4975 & 0.2027 & 0.4392 & 0.0661 & 0.1966 & 0.0980 & 0.1569 \\
\hline Underidentification test ( $\mathrm{p} \_$value) & 0.0013 & 0.0013 & 0.0013 & 0.0013 & 0.0013 & 0.0013 & 0.0013 & 0.0013 \\
\hline $\begin{array}{l}\text { Weak-instrument-robust } \\
\text { inference (minimum p_value) }\end{array}$ & 0.0684 & 0.0662 & 0.0457 & 0.0712 & 0.0754 & 0.0654 & 0.0531 & 0.0810 \\
\hline
\end{tabular}

Notes: clustered robust standard errors by firm in parentheses; *** p $<0.01$, ** p $<0.05$, * $\mathrm{p}<0.1$

Table 2 reports the findings for Equation (1), in which the trading volume and adjusted trading volume are used as liquidity measures. The Hansen test result indicates that the set of instrument variables is not suitable for the idea of an increase in total assets employed as a measure of investment; thus, this kind of investment measurement cannot be adopted in subsequent regressions. The coefficient $\beta$ of liquidity which denotes a negative and significant correlation between liquidity and investment in different definitions of investment implies that higher trading volume causes less firm investment, especially reduced investment in fixed assets and reduced capital expenditure. This result is not compatible with Muñoz's (2012), but is underpinned by Fang (2014), concluding a signicantly negative association between stock market liquidity and firm innovation. It also partly verifies the negative transmission channel for the impact of stock market liquidity on firm investment, particularly via market pressure and managerial myopia.

The effect of Tobin's Q is not consistent for various definitions of investment, but overally, investment of large-sized enterprises in Vietnam is more impacted by growth 
opportunities and prospects. In this respect, Tobin's Q is a fine proxy for series of investment opportunities to function in line with the $\mathrm{Q}$ theory of investment.

The regression results demonstrate a positive and significant debt-investment relation as theoretically expected. Those using high debt are often associated with increased investment expenditure, which is consistent with the theory of tax shield from debt, whereby using a high debt leverage increases firm value. Yet, there have been a few opposite arguments as typically suggested by Muñoz (2012), who maintained that debt leverage negatively and significantly relates to firm investment and attributed overinvestment to the fact that firms with higher levels of debt leverage require more cash flows for principal and interest repayment, thereby reducing investment in new projects.

Cash flow is also found to be positively and significantly related to firm investment. This result indicates similar correlation direction, coefficient magnitude, and significance levels to those in Almeida et al. (2010), explained by the agency and asymmetric information theories.

\section{Table 3}

Estimated results with two measures of liquidity and interacting variables in terms of more share issuance

\begin{tabular}{|c|c|c|c|c|}
\hline \multirow{2}{*}{ Explanatory variable } & \multicolumn{2}{|c|}{ Trading Vol. } & \multicolumn{2}{|c|}{ Trading Vol./Ind. } \\
\hline & PPE (2) & Capex (4) & PPE (2) & Capex (4) \\
\hline \multirow[t]{2}{*}{ Tobin's Q } & $2.3933 *$ & $0.1581 * *$ & $1.7758 *$ & $0.1068 *$ \\
\hline & $(1.2467)$ & $(0.0696)$ & $(0.9443)$ & $(0.0563)$ \\
\hline \multirow[t]{2}{*}{ Trading Vol. } & $-5.5089 * * *$ & $-4.0789 * * *$ & & \\
\hline & $(25.1353)$ & $(1.4435)$ & & \\
\hline \multirow[t]{2}{*}{ Issue * Trading Vol. } & 18.3336 & 0.9791 & & \\
\hline & $(22.8855)$ & $(1.381)$ & & \\
\hline \multirow[t]{2}{*}{ Trading Vol./Ind. } & & & $-0.117 * *$ & $-0.0062 * *$ \\
\hline & & & $(0.0889)$ & $(0.0064)$ \\
\hline \multirow[t]{2}{*}{ Issue * Trading Vol./Ind } & & & -0.0405 & -0.0016 \\
\hline & & & $(0.0512)$ & $(0.0028)$ \\
\hline
\end{tabular}




\begin{tabular}{|c|c|c|c|c|c|}
\hline \multirow{2}{*}{\multicolumn{2}{|c|}{ Explanatory variable }} & \multicolumn{2}{|c|}{ Trading Vol. } & \multicolumn{2}{|c|}{ Trading Vol./Ind. } \\
\hline & & PPE (2) & Capex (4) & PPE (2) & Capex (4) \\
\hline \multirow{2}{*}{\multicolumn{2}{|c|}{ Leverage }} & $1.3794 * *$ & $0.1701 * * *$ & $1.4176^{* *}$ & $0.1783 * * *$ \\
\hline & & $(0.6528)$ & $(0.055)$ & $(0.5953)$ & $(0.0528)$ \\
\hline \multirow{2}{*}{\multicolumn{2}{|c|}{ Cash Flow }} & $0.9895 * *$ & $0.1816^{* * *}$ & $1.1361 * *$ & $0.1878 * * *$ \\
\hline & & $(0.7372)$ & $(0.0634)$ & $(0.73)$ & $(0.0627)$ \\
\hline Hansen test (p-value) & & 0.4978 & 0.4384 & 0.2197 & 0.1680 \\
\hline $\begin{array}{l}\text { Underidentification } \\
\text { (p-value) }\end{array}$ & test & 0.0016 & 0.0016 & 0.0001 & 0.0001 \\
\hline $\begin{array}{l}\text { Weak-instrument-robust } \\
\text { inference (min p-value) }\end{array}$ & & 0.0880 & 0.0856 & 0.0687 & 0.0819 \\
\hline
\end{tabular}

Notes: clustered robust standard errors by firm in parentheses; *** $\mathrm{p}<0.01, * * \mathrm{p}<0.05, * \mathrm{p}<0.1$

The liquidity impact on investment seems to make no difference in the cases of firms with and without share issuance. Nevertheless, the impact bears similar direction and magnitude. This evidence altogether rejects the reasoning relating to the transmission channel that liquidity stimulates investment due to increased share issuance. This result supports the view of transmission channel of liquidity's negative influence on investment that during new issuance, in order to attract huge investment with the tendency of short-term swing trading based on firm-related information and performance, management are often caught in myopic behavior, forgoing long-term benefits from productive investment projects to maintain and enhance current business performance. This significantly reduces investment. 


\section{Table 4}

Estimated results with two measures of liquidity and interacting variables in terms of financial constraints according to firm size

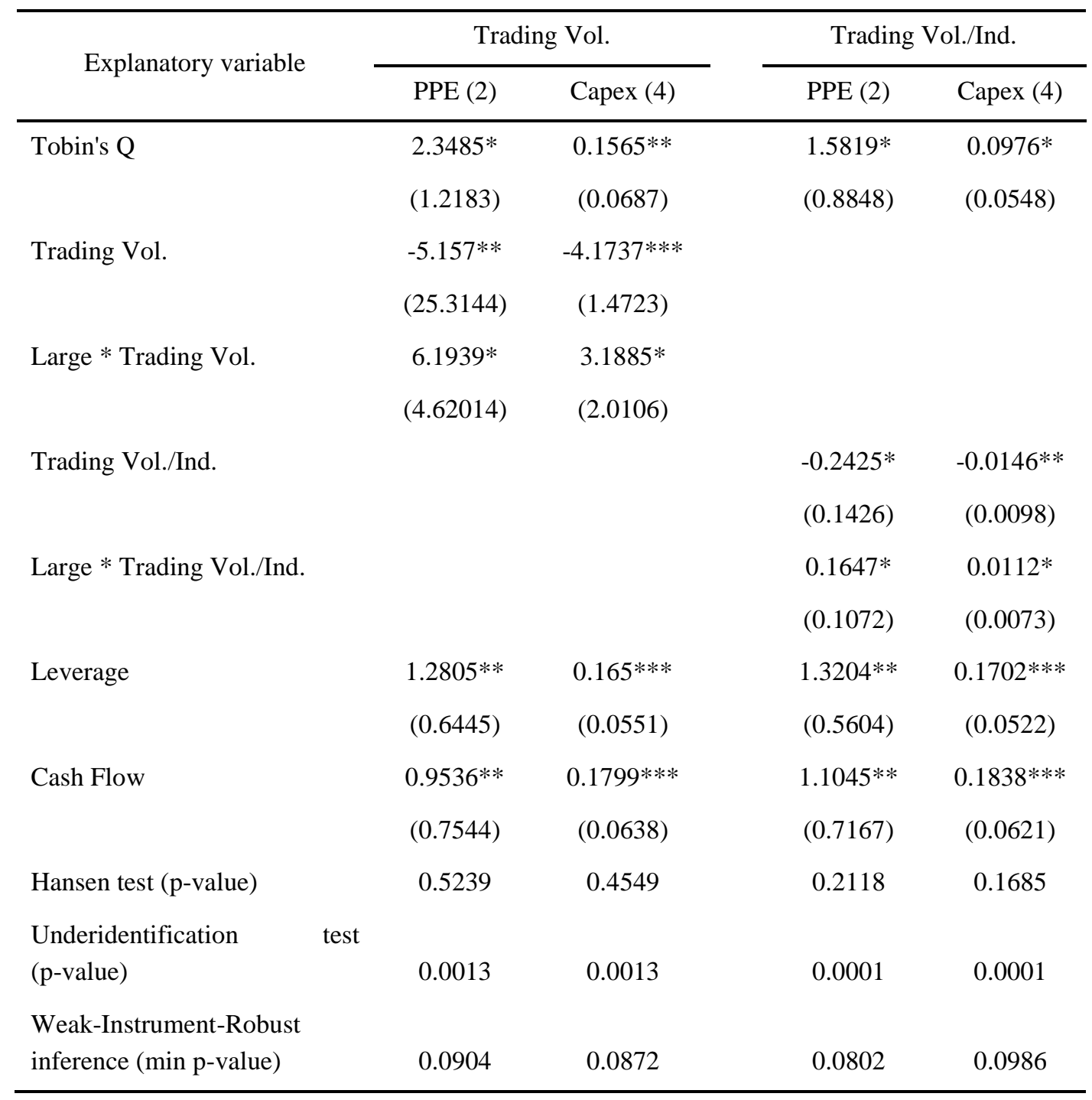

Notes: clustered robust standard errors by firm in parentheses; *** $\mathrm{p}<0.01$, ** $\mathrm{p}<0.05$, $* \mathrm{p}<0.1$

Table 4 indicates an increase in the absolute value of Trading Vol. when we consider the impact of interaction between firm size and liquidity on firm investment. This implies that the negative correlation between trading volume and investment is maintained considering the size of enterprises in the surveyed sample. Regarding testing 
significance concurrently of the variables by Wald test with interacting variables successively for each regression through different measures of liquidity, the test results reject the null hypothesis at 5\% level, implying the suitability of the model and also the significance of liquidity in use as a variable.

\section{Table 5}

Estimated results with two measures of liquidity and interacting variables in terms of firms' investment opportunities

\begin{tabular}{|c|c|c|c|c|}
\hline \multirow{2}{*}{ Explanatory variable } & \multicolumn{2}{|c|}{ Trading Vol. } & \multicolumn{2}{|c|}{ Trading Vol./Ind. } \\
\hline & PPE (2) & Capex (4) & PPE (2) & Capex (4) \\
\hline \multirow[t]{2}{*}{ Tobin's Q } & $2.5029 *$ & $0.168 * *$ & $1.6429 *$ & $0.1002 *$ \\
\hline & $(1.2876)$ & $(0.0712)$ & $(0.8996)$ & $(0.0554)$ \\
\hline \multirow[t]{2}{*}{ Trading Vol. } & $-5.3571 *$ & $-4.4232 * *$ & & \\
\hline & $(36.5183)$ & $(1.8188)$ & & \\
\hline \multirow[t]{2}{*}{ High B/M*Trading Vol. } & 5.085 & 1.0951 & & \\
\hline & $(25.3094)$ & $(1.2883)$ & & \\
\hline \multirow[t]{2}{*}{ Trading Vol./Ind. } & & & $-0.1306^{*}$ & $-0.0063^{*}$ \\
\hline & & & $(0.0916)$ & $(0.0066)$ \\
\hline \multirow[t]{2}{*}{ High B/M*Trading Vol./Ind. } & & & 0.0169 & -0.0013 \\
\hline & & & $(0.0338)$ & $(0.0035)$ \\
\hline \multirow[t]{2}{*}{ Leverage } & $1.3472 * *$ & $0.1705 * * *$ & $1.4545 * *$ & $0.1782 * * *$ \\
\hline & $(0.6476)$ & $(0.0559)$ & $(0.5855)$ & $(0.0529)$ \\
\hline \multirow[t]{2}{*}{ Cash Flow } & $1.0461 * *$ & $0.1858 * * *$ & $1.1652 *$ & $0.1871 * * *$ \\
\hline & $(0.7517)$ & $(0.0637)$ & $(0.724)$ & $(0.0625)$ \\
\hline Hansen test (p-value) & 0.4955 & 0.4350 & 0.1925 & 0.1595 \\
\hline Underidentification & 0.0019 & 0.0019 & 0.0001 & 0.0001 \\
\hline $\begin{array}{l}\text { Weak-instrument-robust } \\
\text { inference (min p-value) }\end{array}$ & 0.0809 & 0.0725 & 0.0684 & 0.0898 \\
\hline
\end{tabular}

Notes: clustered robust standard errors by firm in parentheses; *** $\mathrm{p}<0.01$, ** $\mathrm{p}<0.05$, $* \mathrm{p}<0.1$ 
The regression results with two measures of liquidity including growth in fixed assets and capital expenditure in the equation suggest that the coefficient of interaction between growth opportunity and trading volume is not statistically significant. However, the impact of liquidity on investment still maintains its direction and magnitude. This implies that a negative correlation between trading volume and firm investment remains similar when considering the difference in growth opportunity of the surveyed firms. This results provide evidence against the idea that the 'grow' firm is more sensitive to market characteristics during its investment. Also, the suitable use of the model and significance of liquidity are confirmed through the above tests.

\section{Conclusion and policy implications}

\subsection{Conclusion}

As demonstrated by the findings, stock market liquidity has a negative impact that reduces firm investment via its transmission channels, implying that due to the Vietnam's stock market characterized by swing trading, Vietnamese management is placed under the pressure of business performance in the short run that leads to their myopic behavior and a trade-off between fine investment opportunities and short-term growth. Next, investment of large-sized firms in Vietnam is much affected by growth chances and prospects, and Tobin's Q, in this respect, is a sound proxy for a set of investment opportunities. Furthermore, we have found conclusive evidence of a positive and significant correlation between debt and investment, with leverage as a control variable for sensitivity of investment and cash flow. This hints that firms using much debt are often involved in rising investment expenditure. The study also provides explanations for the use of cash flow as a measure of financial constraints as well as the positive and highly significant association between cash flow and investment at the firm level.

\subsection{Policy implications}

- For firm management:

Due to intense pressure from the stock market and swing trading behaviors that are conducive to managerial myopia in decision-making processes, it is imperative to take into serious consideration the benefits and trade-off between long-term investment opportunities potentially enhancing firm value and short-term business performance. 
Business administrators need to capitalize upon the periods when firm stock liquidity reaches its high level to issue additional shares so as to enjoy low-cost financing for fine investment planning.

- For investors:

Due to the fact that investors tend to adopt swing trading in the market, thus creating pressures for short-term performance of firm management, there is a need to establish long-term investment and/or trading plans. Investors, in light of this study's findings, make investment decisions and effective responses even when they suffer inevitable losses in their transactions.

To investors themselves, logical analyses are pivotal, combining investment opportunities, firm value, and firm performance for long-term planning, rather than referring to short-term business outcome.

- For policy makers:

Information asymmetry and market transparency arouse much interests in the context of Vietnam; therefore, to reduce stock market pressures and set the basis for long-term investments, transparent information should be improved of listed firms for investors' benefits. Through this practice, their trust in the quality of firms' activities could be enhanced.

It is also essential that long-term investment climate be created for investors to generate low-cost financing sources with high levels of stability. These are financial sources bringing about high added value and alleviating the problem of managerial myopia in investment decisions

\section{References}

Admati, A. R., \& Pfleiderer, P. (2009). The Wall Street walk and shareholder activism: Exit as a form of voice. Review of Finance Studies, 22(7), 2645-2685.

Almeida, H., Campello, M., \& Galvao Jr, A. F. (2010). Measurement errors in investment equations. Review of Finance Studies, 23(9), 3279-3382.

Banerjee, S., \& Kremer, I. (2010). Disagreement and learning: Dynamic patterns of trade. Journal of Financial, 65(4), 1269-1302.

Butler, A. W., Grullon, G., \& Weston, J. P. (2005). Stock market liquidity and the cost of issuing equity. Journal of Financial and Quantitative Analysis, 40(2), 331-348. 
Edmans, A., \& Manso, G. (2011). Governance through trading and intervention: A theory of multiple blockholders. Review of Finance Studies, 24(7), 2395-2428.

Fang, V. W., Tian, X., \& Tice, S. (2014). Does stock liquidity enhance or impede firm innovation? Journal of Finance, 69(5), 2085-2125.

Gilchrist, S., Himmelberg, C. P., \& Huberman, G. (2005). Do stock price bubbles influence corporate investment? Journal of Monetary Economic, 52(2005), 805-827.

Lesmond, D. A. (2005). Liquidity of emerging markets. Journal of Financial Economics, 77(2), 411452.

McGahan, A. M., \& Porter, M. E. (1997). How much does industry matter, really? Strategic Management Journal, 18(Summer Special Issue), 15-30.

Muñoz, F. (2012). Liquidity and firm investment: Evidence for Latin America. Journal of Empirical Finance, 20(2013), 18-29.

Polk, C., \& Sapienza, P. (2009). The stock market and corporate investment: A test of catering theory. Review of Finance Studies, 22(1), 188-217.

Porter, M. (1992). Capital disadvantage: America's failing capital investment system. Harvard Business Review, 70(5), 65-82.

Sadka, R., \& Scherbina, A. (2007). Analyst disagreement, mispricing, and liquidity. Journal of Finance, 62(5), 2367-2404.

Stein, J. (1988). Takeover threats and managerial myopia. Journal of Political Economy, 96(1), 61-80.

Stein, J. (1989). Efficient capital market, inefficient firms: A model of myopic corporate behavior. Quarterly Journal of Economics, 104(4), 655-669.

Stein, J. (1996). Rational capital budgeting in an irrational world. Journal of Business, 69, 429-455. 